\title{
Matlab Analysis of Lubrication Effect on Temperature and Rate of Fuel Consumption Using Variable ICE Parameters.
}

\section{Motey Festus and Dr.Essel Ben Hagan}

\section{NOMENCLATURE. \\ IMEP Indicated Mean Effective Pressure \\ ICE Internal Combustion Engine}

\begin{abstract}
ICE efficiency has been the main focus of research internationally so as to reduce associated problems of liquid fossil fuel consumption and gaseous emissions. Heat generation within ICE is due to friction and burning of fuel internally which results to mechanical losses as well as excessive fuel consumption. The engine block is composed of pistons surrounded by piston rings which move within hollow cylinders collectively known as piston - cylinder compact. This piston motion results to friction between metals. Lubricants are oils used to reduce friction. Objectively, this research will use modeling and simulation tools to analyze the models with incorporation of the factors to observe trends in friction reduction or effective lubrication leading to reduction in liquid fuel consumption. Frictional forces, gas pressures and automobile motion are considered in this literature as factors that influence internal combustion. The nature of motion between piston and inner cylinder liner will result to hydrodynamic, mixed and boundary lubrication. The methodology adopted by this research is modeling and simulation of previous as well as new models. The new models consist of old models with incorporated factors. Matlab programs and simulation of models will revise these models which will generate graphical results for trends to be established.
\end{abstract}

Key words: Cavitation; Simulation; Combustion; Lubrication; Fuel.

\section{INTRODUCTION}

Better engine performance, lower fuel consumption or fuel consumption or fuel economy, total efficiency as well as lowering exhaust emissions are main areas of making further research into for ICEs or automobile engines improvement. Thus, there is need for continuous research into mechanical engineering applications so that further reduction in piston ring - liner friction heat generation as well as heat generation due internal combustion can be achieved.Ferguson and Kirkpatrick, (2001);Andrew, Robert and Jhon, (2002). The largest mechanical losses are due to this heat generation. Thus, more mechanical energy has to be used to overcome causes of heat generation. Piston assembly consists of piston, piston rings, lubricants and cylinder. Since the beginning of use of ICE, piston assembly is always lubricated by using lubricants. Commonly used lubricants are engine oils. Therefore, there is need for continuous improvement of ICE lubricating systems so as to reduce frictional effect heat 
losses. Lubrication formulation, piston assembly design and development of accurate internal combustion processes are also factors to be considered for heat reduction as well as liquid fuel consumption.Barry and Alan, (2002). Previously, experiments were done to measure or quantify piston assembly friction. Experiments such as coating liner methods are accompanied with problems like vibrations, effects of piston side force on sensor and gas sealing at liner top end effect. By an experimental method of coating liner assembly, the cylinder liner is isolated from engine block of ICE so that a special gas sealing arrangement is made at cylinder head liner interface.Bosech, (2004). This method of coating liner is basically not accurate and may not give true reflection of results, so it needs modifications. Piston assembly frictional force is obtained indirectly by measuring forces that act on connecting rod as well as on piston assembly through IMEP method. Abdullah, Kurniawen and Shamsudeen, (2008). This IMEP method needs no sensors in order to obtain accurate results. Relatively, the advantage of IMEP method is that ICE needs no modifications to achieve accurate results. However, matlab modeling and simulation are methodological tools that were adopted by this research to analyze friction in piston assembly of ICEs. The objective of this research or article is to analyze these models or equations by incorporating ICE parameters such as number of piston rings, connecting rod weight, number of pistons, piston diameter and temperature (engine heat generated) into these models to determine their effects on lubrication performance which intend affect total engine temperature as well as rate of liquid fuel consumption.Grant, (2004);Sotaria Bhatt and Mistry, (2009).

\section{LITERATURE REVIEW}

Piston assembly friction, weight of piston assembly, connecting rod force, piston assembly inertial force as well as gas force acting on piston assembly in the direction along central axis of cylinder liner are frictional design factors to be considered. Gas force is axial force exerted by combustion pressure on piston assembly. Gas force acting on piston crown, connecting rod force, weight of piston assembly, inertial force and piston assembly frictional force are forces that act on piston assembly directly in line with central axis of cylinder liner.Sandoval and Heywood, (2003); Khurmi and Gupta, (2007); Herbst, (2007). Basically, IMEP method in principle measures piston assembly frictional losses with the aid of forces mention above.

Speed varies throughout all complete engine cycles. Angular acceleration of crankshaft has influence on axial acceleration of piston assembly. Piston assembly experiences force due to combustion pressure which is referred to as gas pressure. Gas force is known as axial force, it is the product of net cylinder pressure and average cylinder bore area.Kikurch, Ito and Nakayama, (2003); Johansen, England,Johannesen and Kvamsdal, (2003). Taking measurements of diameter at different points to find average diameter is a step procedure to calculate bore area. Relative sensitivity to environmental conditions, low power consumption, light weight, small size as well as high frequency response are factors which influence piezoelectric transducer pressure measurements and are referred to as cylinder pressure measurements. Long term temperature drift and pegging are eliminated when using piezoelectric pressure transducers to determine comparable pressure which is related to an absolute value. 
Since invention of ICEs, the mode of friction reduction has been application of lubricants or engine oils. The nature of piston ring shape as well as surfaces of contact within piston - cylinder liner assembly has resulted to classification of three different modes of lubrication. Pure hydrodynamic, mixed and pure boundary lubrication are the three classes of lubrication. Also, due to roughness, some portions of surfaces may be in direct contact resulting to experiencing pure boundary lubrication. When conditions exist such that no engine oil is found between piston ring and liner, then pure boundary lubrication is said to occur. Thus, load of ring is directly resting on liner.Agostino, Maresca and Senatore, (2006).Conditions of pure boundary lubrication will result to friction between surfaces in contact in piston ring - liner assembly such that piston ring load is fully supported by asperity contact.Mixed lubrication occurs when there is oil between certain portions of piston ring - liner contact whiles there is no oil between certain portions of contact. When enough quantity of engine oil or lubricant is between piston ring - liner surfaces in contact, then pure hydrodynamic lubrication condition is said to occur.Dwyer - Joyce, Drinkwater and Danohoe, (2003); Taylor and Evans, (2004). Thus, there is wetting between these surfaces whiles no asperity contact occur between these surfaces. Frictional forces for hydrodynamic lubrication can be obtained using factors of film height, film width as well as shear stress or principles of conservation of mass and momentum. Viscosity of lubricant is affected by temperature distribution along liner of cylinder assembly. Piston ring motion will cause increase in liner temperature resulting to low lubricant viscosity. Friction generation in piston assembly is affected by combustion chamber pressure.Priest and Taylor, (2002);Burke, Brace, Lewis, Cox and Pegg, (2011).

\section{METHODOLOGY}

Previous authors have analyzed models or mathematical equations in this article but did not use software tools of simulation and modeling. They did not incorporate these engine parameters into these models for re - simulation as well as re - modeling.Coombes, Hunt, Lipsman, Osborn and Struck, (2000);Meyer, (2007).Methodology used by this article is modeling and simulation to re - analyze these models in terms of the engine parameters. Thus, conclusion as well as recommendation for academia, manufacturers and legislators will be deduced. These models consist of different alphabets that represent frictional processes, frictional components, corrections, wear and tear.Chapman, (2004). This methodology is quantitative and gives detail of how research objectives will be achieved. The modeling involves writing and running matlab programs to obtain graphical results as well as establish trends. Simulation of models will also produce graphical results. During simulation, representative components offriction are picked from simulink libraries and linked by connecting lines to build internal combustion engines. The representative engines are run and scoped for analysis due to development in technology.Cooper, (2001);Bayrakar and Durgun, (2003).

EQUATIONS OR MODELS

Brake Mean Effective Pressure

Equation 1

$$
\text { bmep }=\frac{P \times z}{V_{d} \times n}
$$




\section{Source: Kanne, 2000.}

The equation above represents a model for brake mean effective pressure of ICE.

Where

$V_{d}=$ Displaced cylinder volume

$\mathrm{s}=n=$ Rotational speed

$Z=$ Number of crank revolutions per power stroke

$P=$ Power of engine.

Heat Transfer

Equation 116

$$
\stackrel{*}{Q}_{c, e b}=z_{c} \times \alpha_{c} \times A_{e b} \times\left(T_{e n g, m}-T_{e b}\right)
$$

Source: Kanne, 2000.

The equation (116) one hundred and sixteen above is a sub - model for heat transfer between the coolant and engine block.

Where:

$z_{c}=$ Number of cylinder

$\alpha_{c}=$ Coolant heat transfer coefficient

$A_{e b}=$ Area of engine block

$T_{\text {eng, } m}=$ Temperature of engine cylinder wall

$T_{e b}=$ Temperature of engine block.

Internal Constant Engine Efficiency

Equation 120

$$
\text { fuel mep }=\frac{z \times \stackrel{*}{m_{f}} \times H_{f}}{V_{d} \times n}
$$

Source: Kanne, 2000.

The equation above represents a model for mean effective pressure of liquid fuel in the engine.

Where

$\stackrel{*}{m_{f}}=$ Mass flow

$H_{f}=$ Fuel heating value

$T_{m}=$ engine temperature

$\mathrm{T}=$ engine temperature

$V_{d}=$ displaced volume

$\mathrm{n}=$ engine power

$\mathrm{z}=$ number of brake revolutions per power stroke

$\mathrm{t}=$ environmental temperature

Load Dynamics

Equation 121

$$
P_{b}(n)=K_{b} n^{3}
$$

Source: Amini, MirzeaiKhoshbakhti, (2013).

This equation above is a model for engine load. 


\section{Where:}

$K_{b}=$ engine load

$n$ = engine speed RPM

$P_{b}=$

$\mathrm{A}=$ age

$\mathrm{V}=$ velocity

Maximum Attainable Tractive Force

Equation 125

Source: Yue, (2008).

$$
F_{\text {max }}=9.8066 \times P_{m t a} \times M \times \mu
$$

The equation (125) one hundred and twenty five above represents a model for tractive force in terms of power and efficiency as well as maximum attainable tractive force in terms of mass.

Where:

$\mathrm{M}=$ Mass of vehicle or automobile.

$F_{\text {max }}=$ Maximum attainable tractive force $(\mathrm{N})$

$P=$ Maximum engine power $(\mathrm{kW})$

$V=$ Vehicle speed $(\mathrm{km} / \mathrm{h})$

$\mu=$ Coefficient of friction between vehicle tires and pavement

Model for Rolling Resistance

Equation 230

$$
R_{r}=9.8066 \times C_{r} \times\left(C_{2} V+C_{3}\right) \times \frac{M}{1006}
$$

Source: Yue, (2008).

Equation (130) one hundred and thirty above is a model representing aerodynamic resistance.

Where:

$R_{r}=$ rolling resistance $(\mathrm{N})$

$\mathrm{M}=$ vehicle mass

$\mathrm{V}=$ vehicle speed

$C_{r}, C_{2}, C_{3}=$ rolling resistance constants

\section{MODELING OF EQUATIONS}

Matlab Program for Equation (108) One Hundred and Eight.

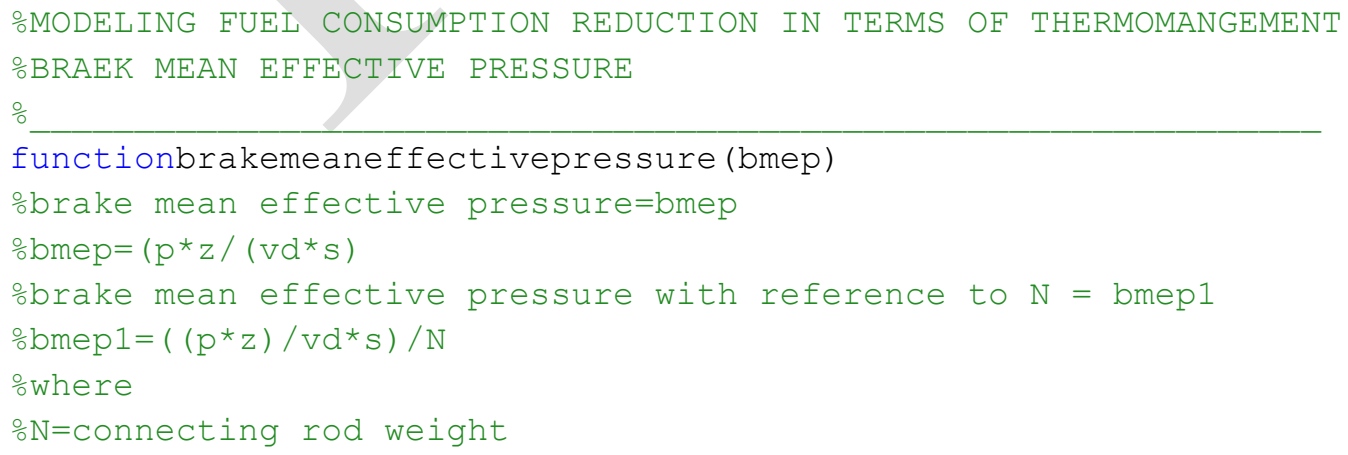


DOI : https://dx.doi.org/10.26808/rs.ed.i8v2.02

International Journal of Emerging Trends in Engineering and Development

Issue 8, Vol.2 (February- March 2018)

Available online on http://www.rspublication.com/ijeted/ijeted_index.htm

ISSN 2249-6149

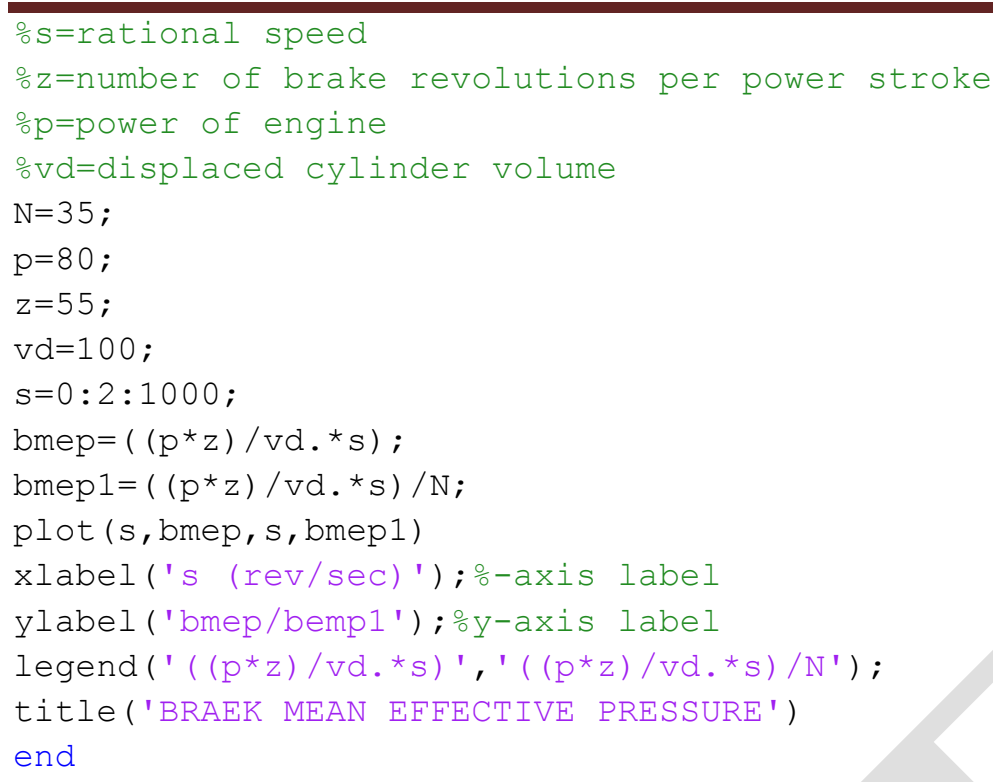

The equation" bmep" has been modified to "bmep1" by this research by incorporating N.

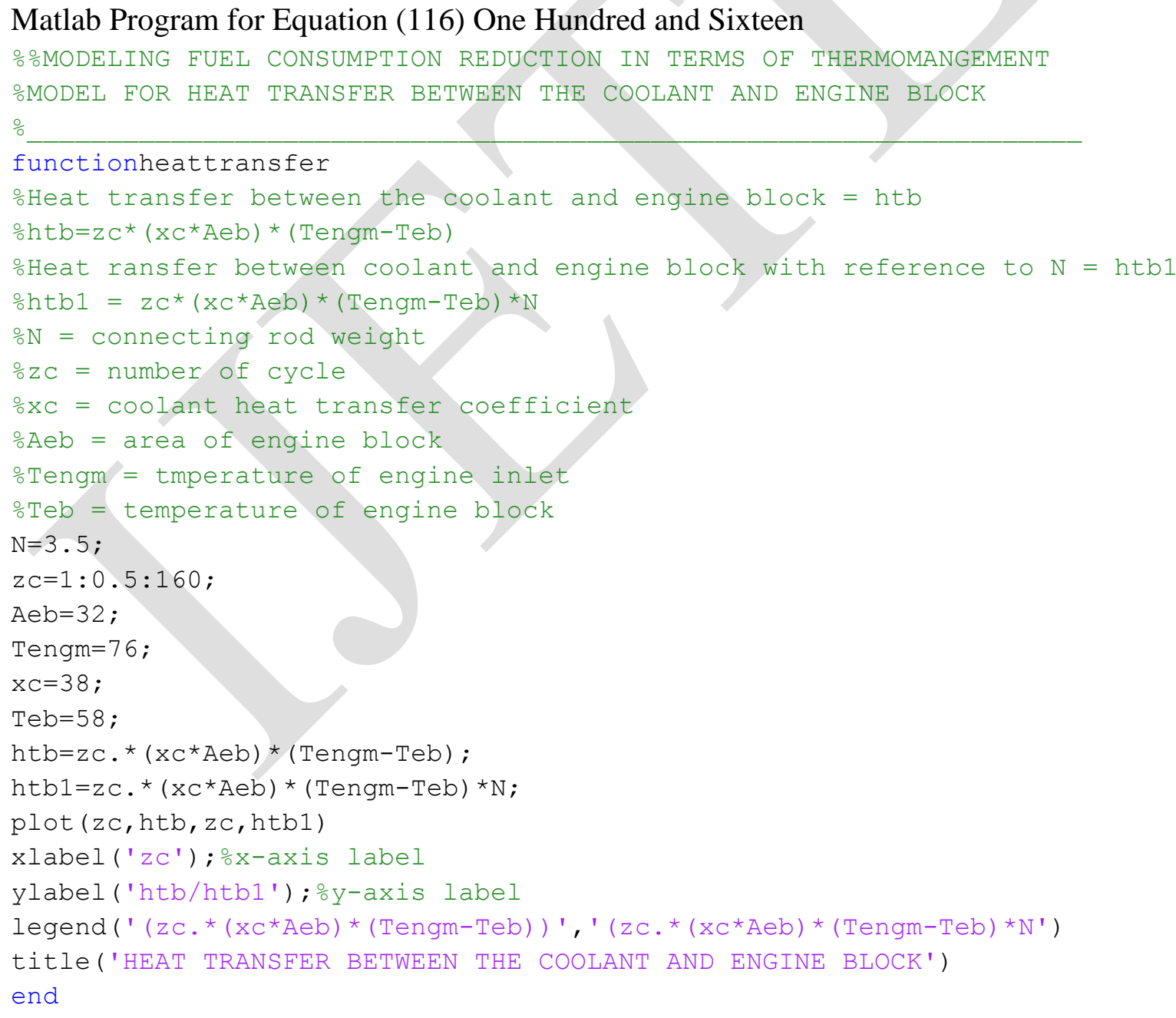


DOI : https://dx.doi.org/10.26808/rs.ed.i8v2.02

International Journal of Emerging Trends in Engineering and Development

Issue 8, Vol.2 (February- March 2018)

Available online on http://www.rspublication.com/ijeted/ijeted_index.htm ISSN 2249-6149

Analyzing equation "htb" was done by the previous author but has been remodeled by this research to form equation "htb1" through the incorporation of $\mathrm{N}$.

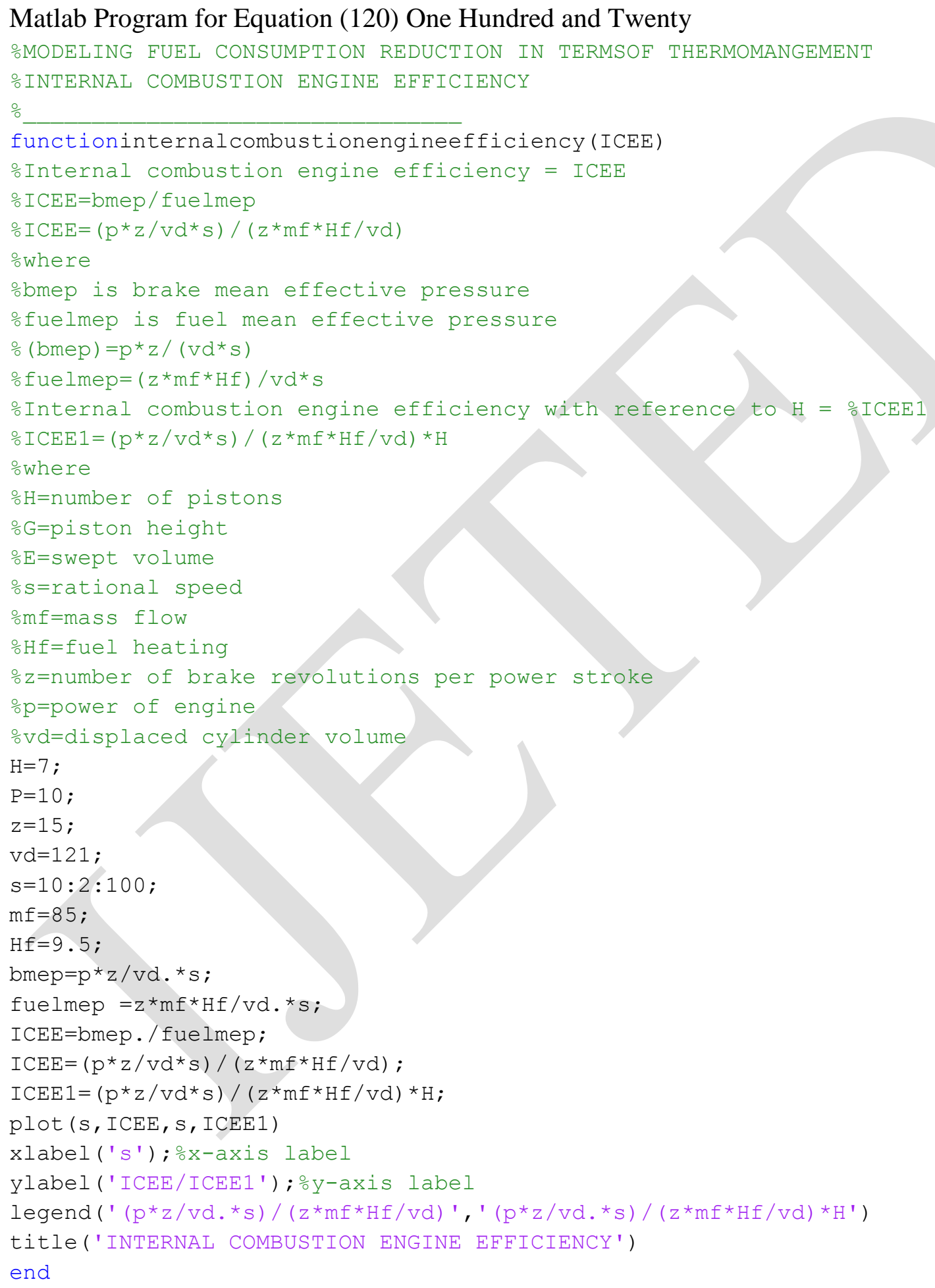

The equation "ICEE" has been remodeled by this research to form equation "ICEE1" by multiplying or incorporating the effect of $\mathrm{H}$. 
DOI : https://dx.doi.org/10.26808/rs.ed.i8v2.02

International Journal of Emerging Trends in Engineering and Development

Issue 8, Vol.2 (February- March 2018)

Available online on http://www.rspublication.com/ijeted/ijeted_index.htm

ISSN 2249-6149

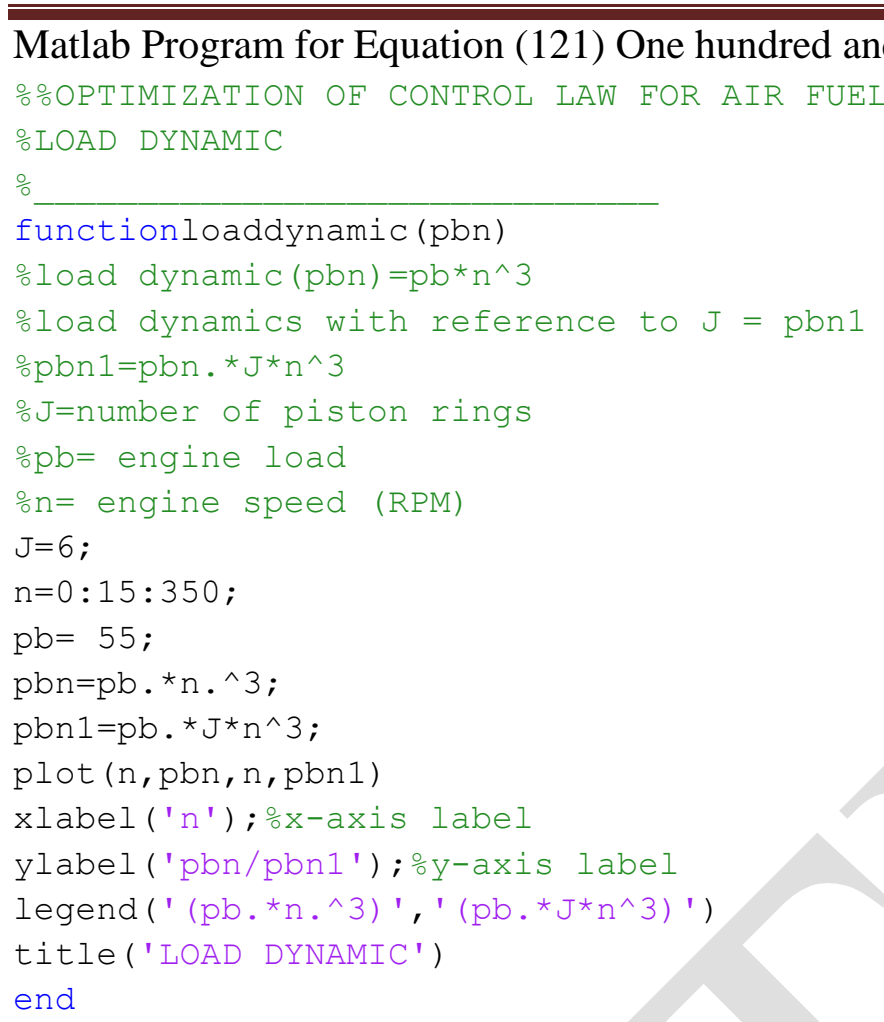

Equation "pbn" was remodeled by this research to form equation "pbn1" by multiplying or incorporating $\mathrm{J}$.

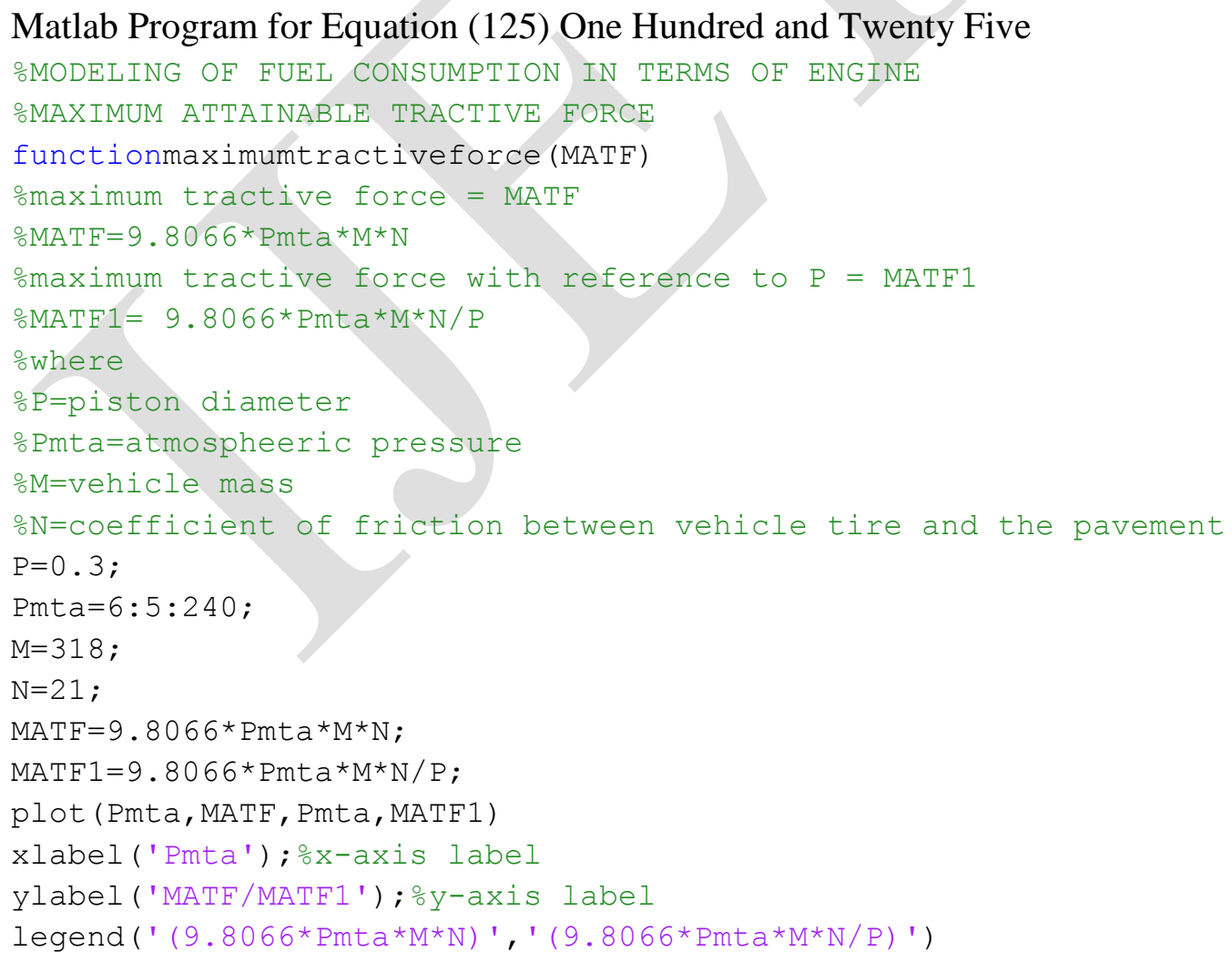


DOI : https://dx.doi.org/10.26808/rs.ed.i8v2.02

International Journal of Emerging Trends in Engineering and Development

Issue 8, Vol.2 (February- March 2018)

Available online on http://www.rspublication.com/ijeted/ijeted_index.htm

title('MAXIMUM ATTAINABLE TRACTIVE FORCE')

end

This equation "MATF" has been remodel by this research to form equation "MAFT1" by incorporating P.

Matlab Program for Equation (130) One Hundred and Thirty.

○MODELING OF FUEL CONSUMPTION IN TERMS OF ENGINE

MODEL FOR ROLLING RESISTANCE

functionrollingresistance ( $\mathrm{Rr})$

\%Rolling resistance $=\mathrm{Rr}$

$\circ \mathrm{Rr}=9.8066{ }^{*} \mathrm{Ca} *(\mathrm{Cb} * \mathrm{~V}+\mathrm{CC}) * \mathrm{M} / 1000$

\%Rollingrsistance with reference to $\mathrm{N}=\mathrm{Rr} 1$

$\circ \mathrm{Rr} 1=\left(9.8066{ }^{*} \mathrm{Ca} *(\mathrm{Cb} * \mathrm{~V}+\mathrm{CC}) * \mathrm{M} / 1000\right) * \mathrm{~N}$

owhere

$\circ \mathrm{N}=$ connecting rod weight

$\therefore \mathrm{Ca}=$ rolling resistance constant

$\circ \mathrm{Cb}=$ rolling resistance constant

$\therefore \mathrm{Cc}=$ rolling resistance constant

$\circ \mathrm{v}=$ vehicle speed

$\% \mathrm{M}=$ vehicle weight

$\therefore \mathrm{Ca}, \mathrm{Cb}, \mathrm{Cc}=$ rolling resistance constant $=45$

$\mathrm{Ca}=45$

$\mathrm{Cb}=45$;

$\mathrm{CC}=45$;

$\mathrm{N}=35$;

$\mathrm{M}=300$;

$\mathrm{V}=15: 5: 250$;

$\mathrm{Rr}=9.8066{ }^{*} \mathrm{Ca} *\left(\mathrm{Cb} \cdot{ }^{*} \mathrm{~V}+\mathrm{CC}\right) \cdot{ }^{*} \mathrm{M} / 1000$;

$\mathrm{Rr} 1=9.8066{ }^{*} \mathrm{Ca}{ }^{*}\left(\mathrm{Cb} \cdot{ }^{*} \mathrm{~V}+\mathrm{CC}\right) \cdot{ }^{*} \mathrm{M} / 1000{ }^{*} \mathrm{~N}$;

$\operatorname{plot}(\mathrm{v}, \operatorname{Rr}, \mathrm{v}, \operatorname{Rr} 1)$

xlabel ('v(m/s^2)'); \% $\mathrm{x}$-axis label

ylabel ('Rr, Rr1') ; \%y-axis label

legend $\left('\left(9.8066{ }^{*} \mathrm{Ca} *\left(\mathrm{Cb} \cdot{ }^{*} \mathrm{~V}+\mathrm{CC}\right) \cdot{ }^{*} \mathrm{M} / 1000\right)\right.$ ', ' $\left.\left(9.8066{ }^{*} \mathrm{Ca} *\left(\mathrm{Cb} \cdot{ }^{*} \mathrm{~V}+\mathrm{CC}\right) \cdot{ }^{*} \mathrm{M} / 1000\right){ }^{*}{ }^{\prime}\right)$

title('ROLLING RESITANCE')

end

The modification of equation " $\mathrm{Rr}$ " by this research was done by incorporating $\mathrm{N}$ to form the equation "Rr1". 
DOI : https://dx.doi.org/10.26808/rs.ed.i8v2.02

International Journal of Emerging Trends in Engineering and Development Issue 8, Vol.2 (February- March 2018) Available online on http://www.rspublication.com/ijeted/ijeted_index.htm

\section{SIMULATION OF EQUATIONS}

Simulation scheme for equation 108

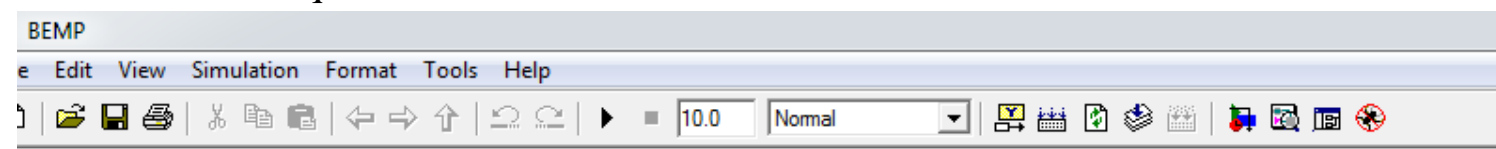

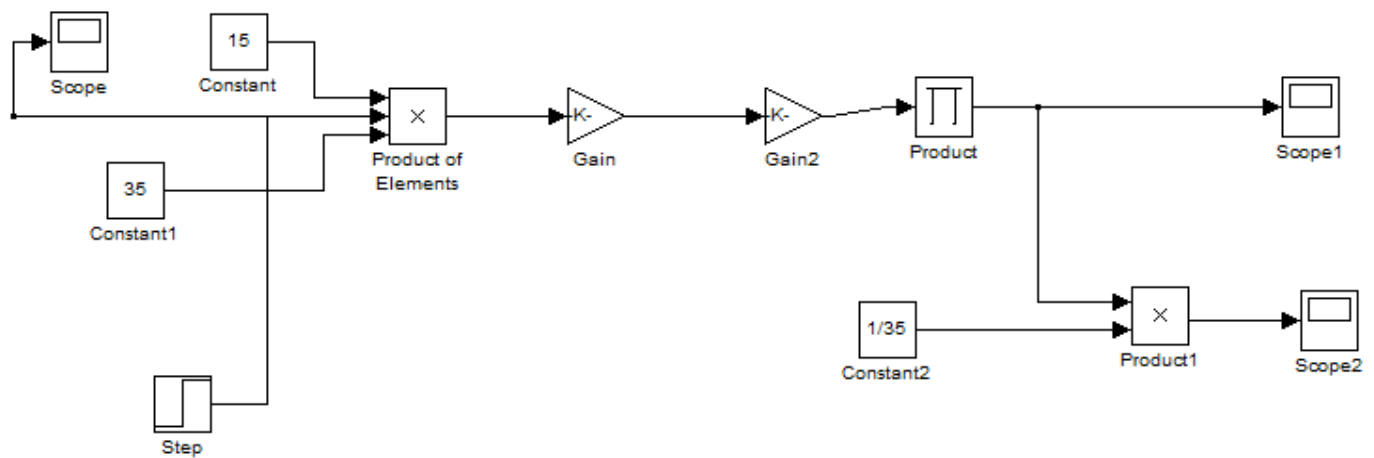

Simulation scheme for equation 116

HEATTRANFE
Edit View Simulation Format Tools Help

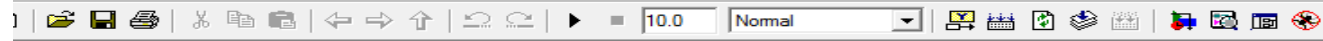

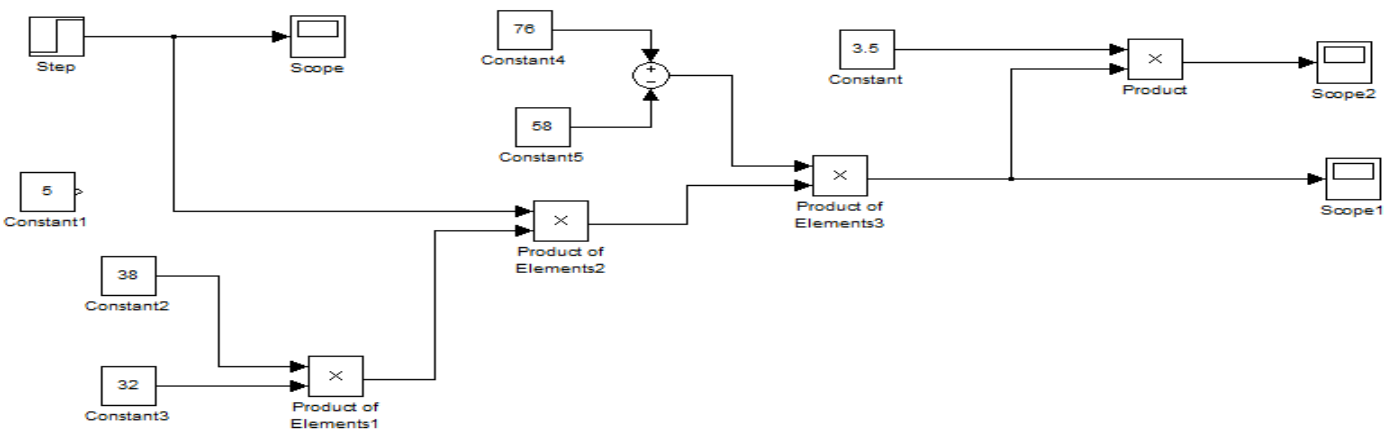

Simulation scheme for equation 120

e Edit View Simulation Format Tools Help

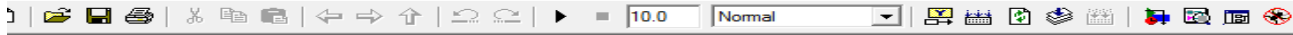

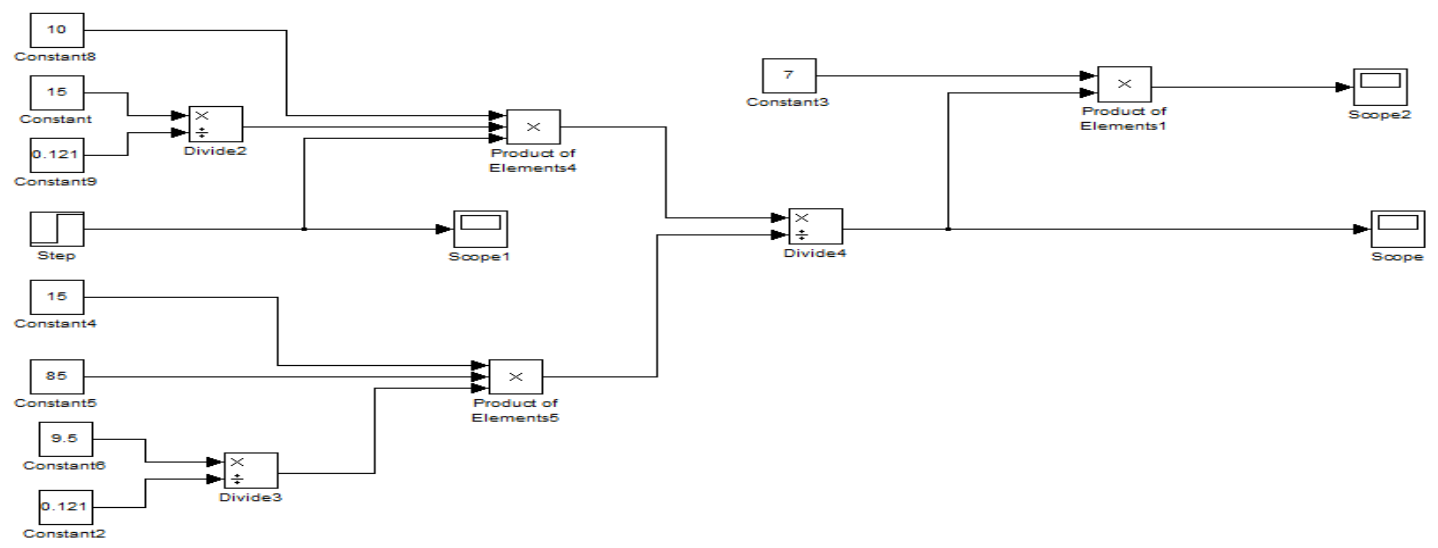


DOI : https://dx.doi.org/10.26808/rs.ed.i8v2.02

International Journal of Emerging Trends in Engineering and Development

Issue 8, Vol.2 (February- March 2018)

Available online on http://www.rspublication.com/ijeted/ijeted_index.htm

Simulation scheme for equation 121

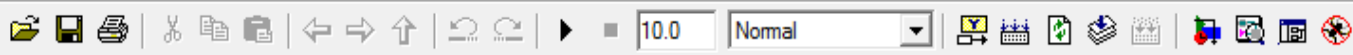

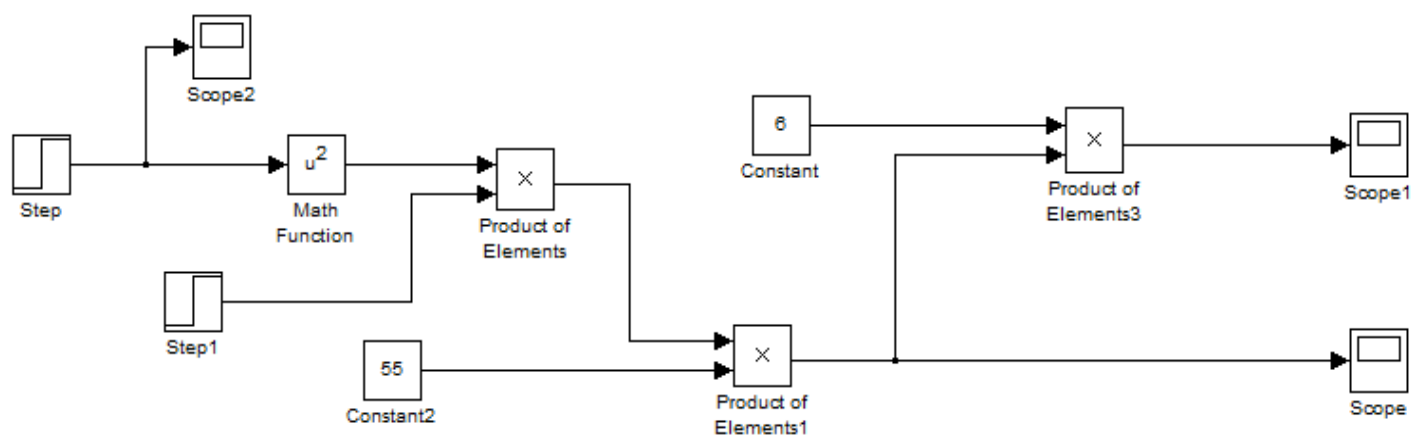

Simulation scheme for equation 125
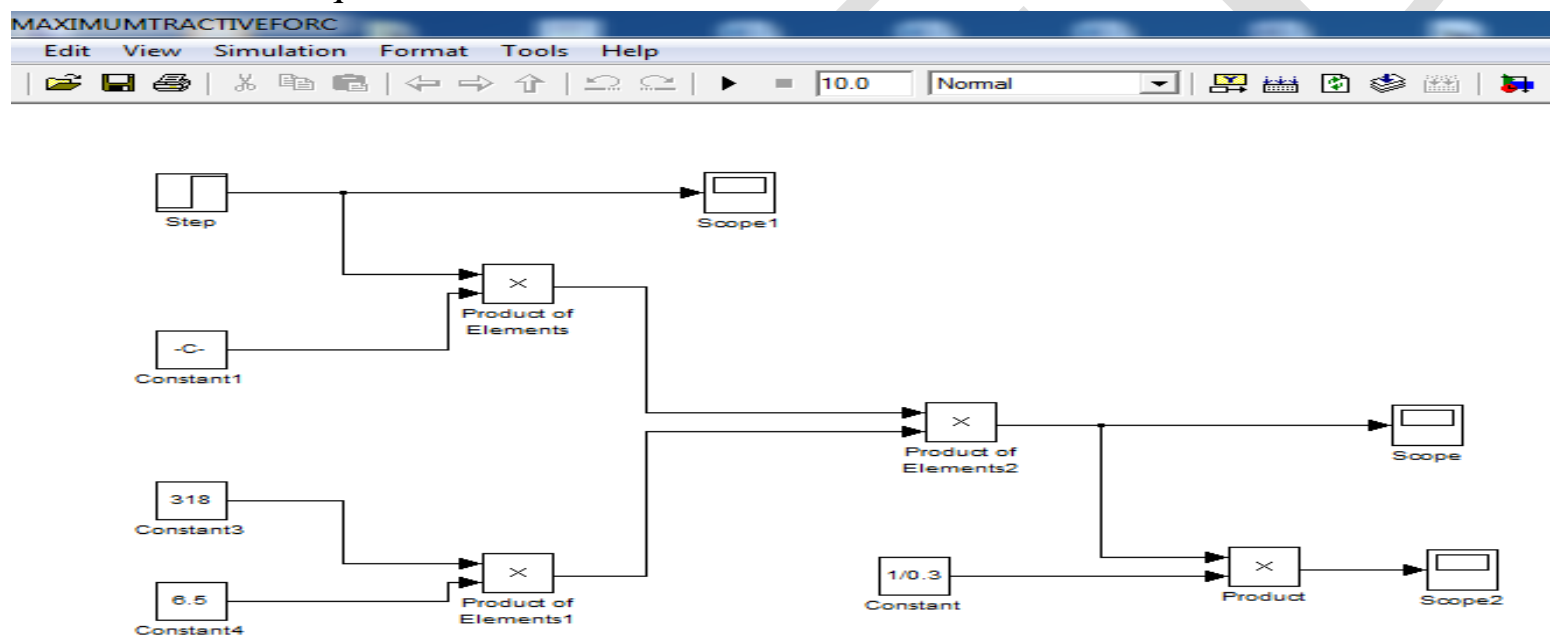

Simulation scheme for equation 130

1. ROLUNGRESSITAN

ile Edit View Simulation Format Tools Help

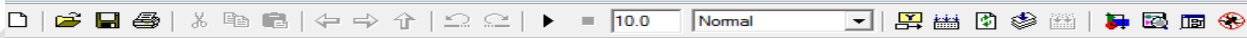
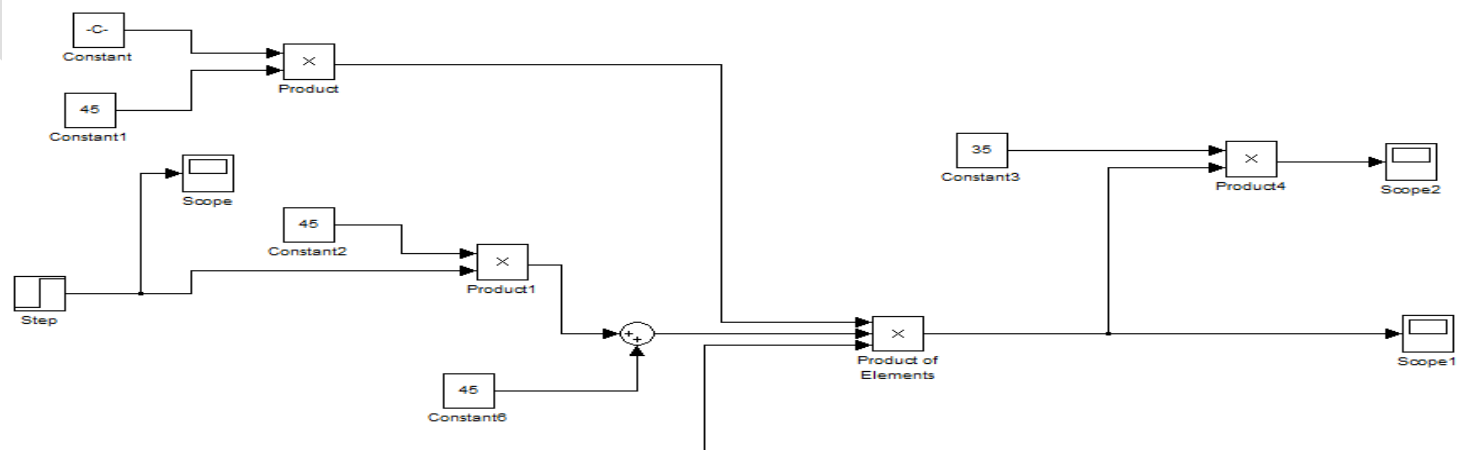


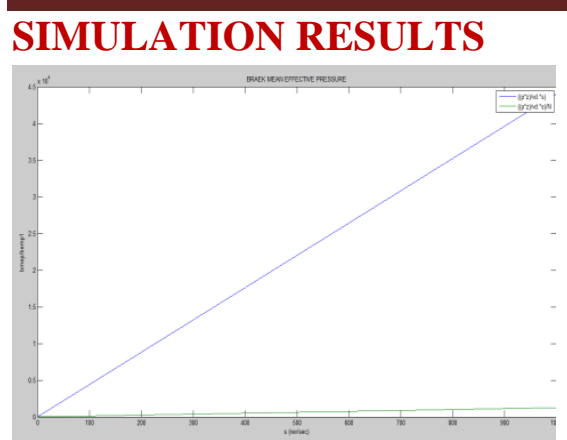

Modeling results for equation 108

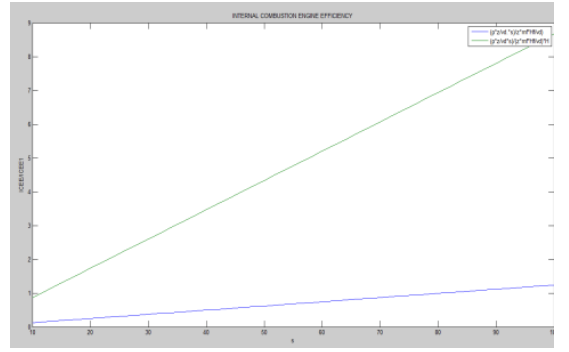

Modeling results for equation 120

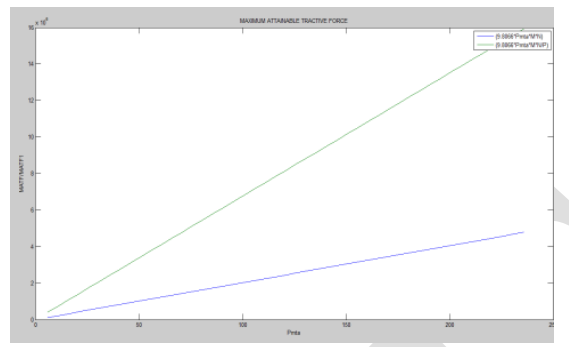

Modeling results for equation 125

SIMULATION RESULTS

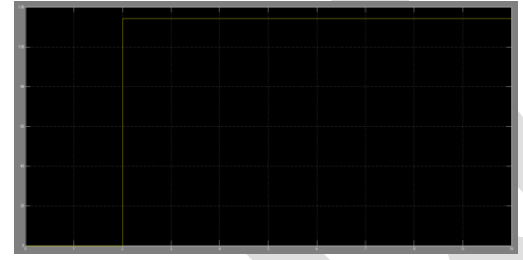

Simulation result i for equation 108

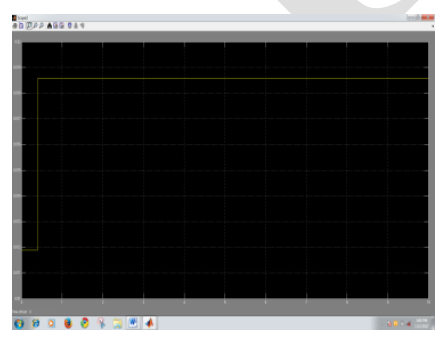

Simulation result i for equation 116

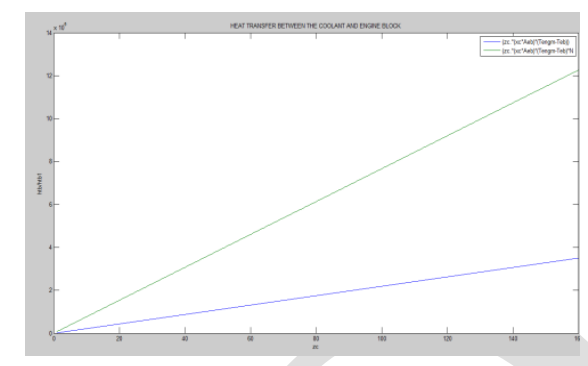

Modeling results for equation 116

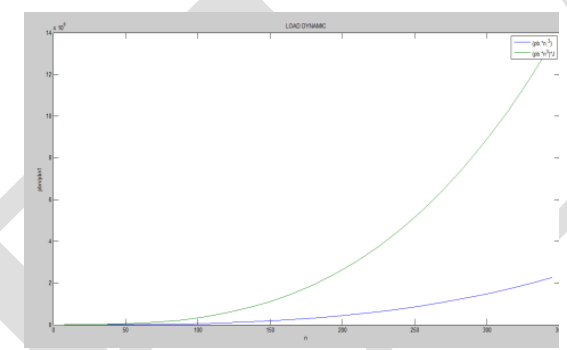

Modeling results for equation 121

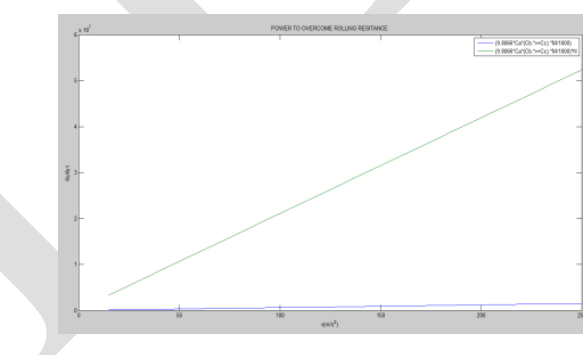

Modeling results for equation 130

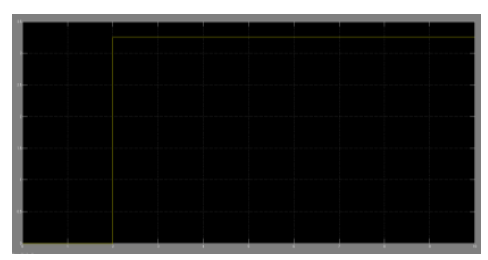

Simulation result ii for equation 108

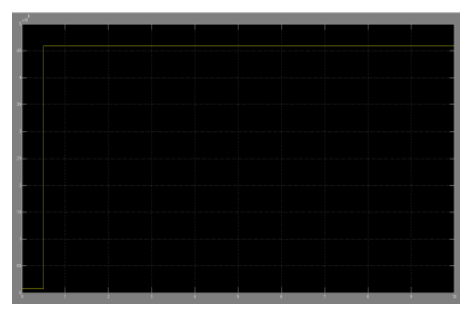

Simulation result ii for equation 116 


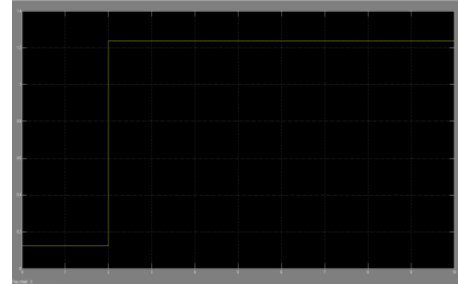

Simulation result i for equation 120

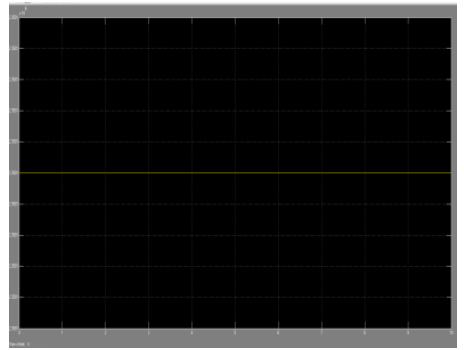

Simulation result i for equation 121

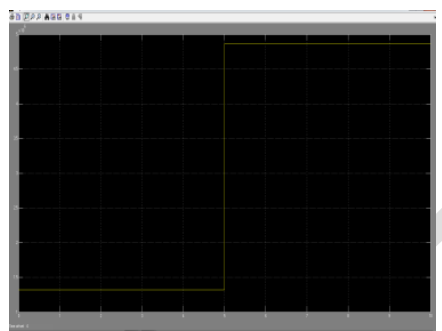

Simulation result for equation 125

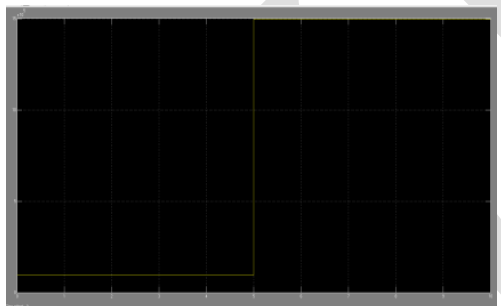

Simulation result i for equation 130

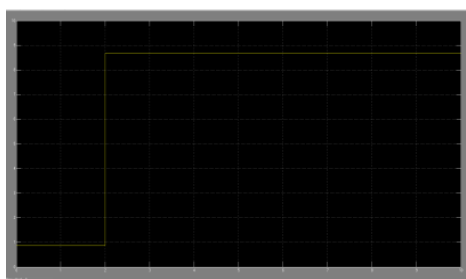

Simulation result ii for equation 120

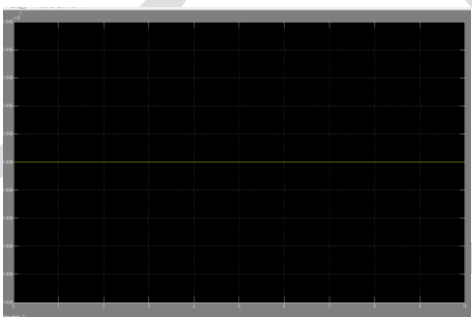

Simulation result ii for equation 121

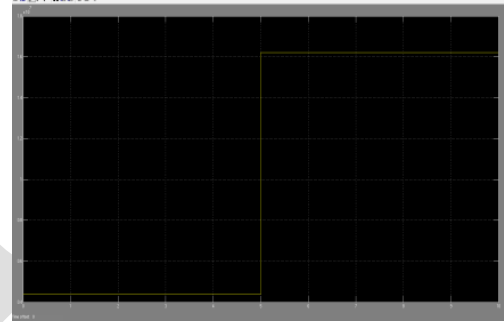

Simulation result ii for equation 125

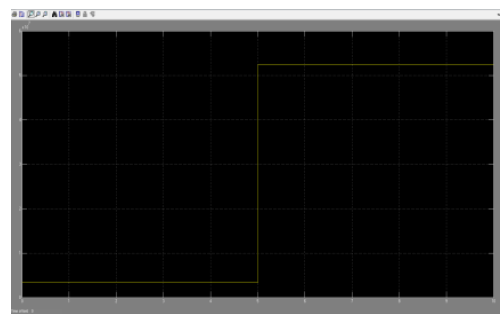

Simulation result ii for equation 130

\section{ANALSIS OF RESULTS}

Values of parameters of ICEs such as number of pistons, weight of connecting rod,number of piston rings, engine temperature and diameter of piston were incorporated into the equations or models to determine their effect on lubricant performance which also affect total engine temperature as well as rate of fuel consumption. Blue line graphs represent modeling results of models or equations for previous authors whiles green lines indicatemodeling revised models or equations after parameter incorporations. 
Thus, for equation 108 the break mean effective pressure reduces after remodeling indicating less pressure effect on lubrication. As pressure decreases then temperature will also decrease and their effects on lubrication will reduce. After parameter remodeling of equation 116, the results indicate increase in heat flow from block to coolant which implies that less heat remains in ICE to have effect on lubrication leading to decrease in temperature. Comparatively, equation 120 results show that ICE efficiency has increase revealing less effect of temperature on lubrication and rate of fuel consumption. Equation 121 results indicate that ICE has produce more power to overcome load after remodeling, which means effective lubrication leading to less heat and less rate of fuel consumption. Results of equation 125 indicate that maximum attainable tractive force produced by ICE has increase due to effective lubrication leading to less temperature and lower rate of fuel consumption. Equation 130 results show that ICE produces more power to overcome rolling resistance after remodeling. Therefore, efficiency is improved, less temperature effect on lubrication and less heat produced.

Simulation result ii for equation 108 shows lesser break mean effective pressure resulting to reduced temperature effect on lubrication and less temperature rise. As indicated in result ii for equation 116 more heat flows out to coolant resulting to effective lubrication and lower engine temperature. Re simulation of equation 120 reveals increase in efficiency, lesser effect due to heat on friction. Result ii of equation 125 reveals maximum attainable force that reduces temperature effect on lubrication. Simulation result ii for equation 130 indicates ICE produce more power which reduces rolling resistance and causes effective lubrication.

\section{CONCLUSIONS AND RECOMMENDATIONS.}

The piston ring and connecting rod parameters have reducing effect on temperature as well as rate of fuel consumption. Therefore, these parameters must be utilized for better fuel savings and also to reduce depletion of underground fossil fuel.

\section{REFERENCES}

I. Abdullah, S., Kurniawen, W. H. and Shamsudeen, A. (2008). "Numerical Analysis of the Combustion Process in a Compressed Natural Gas Direct Injection Engines". Department of Mechanical and Materials Engineering, National University of Malaysia, Journal Applied Fluid Mechanics.

II. Agostino, V. D., Maresca, P. and Senatore, A. (2006).“Theoretical Analytical for Frictional Losses Minimization in Piston Rings".International Conference on Tribology.

III. Amini, A., Mirzaei, M. and Khoshbakhti, S. R. (2013) "Optimization - base Non - Linear Control Law with Increased Robustness for Air Ratio Control in SI Engine". International of Automotive Engineering.

IV. Andrew, N., Robert, S. and Jhon, C. A. (2002).Heavy Duty Track System $2^{\text {nd }}$ Edition.McGraw - Hill (Publisher).

V. Barry, W. and Alan, A. (2002).Diesel Engines and Fuel Systems.McGraw - Publishing Company. 
VI. Bayrakar, H. and Durgun, O. (2003)."Mathematical Modeling of Spark Ignition Engine and Simulations Engine Cycle". Energy Sources, 25(5), pp. 439 - 455.

VII. Bosech, R. (2004). Bosch Gasoline - Engine Management.Bentley Publishers.

VIII. Burke, R. D., Brace, C. J., Lewis, A., Cox, A. and Pegg, I. (2011).“Analysis of Energy Flow in Engine Coolant Structure and Lubricant Warm - up".Institution of Mechanical Engineering/Journal for Society of Automobile Engineers, International Conference, VTMS 10.

IX. Chapman, S. J. (2004). MATLAB Programing for Engineers. Thomson (Publisher).

X. Coombes, K. R., Hunt, B. R., Lipsman, R. L., Osborn, J. E., and Struck, G. J. (2000). Differential Equation with MATLAB.John Wiley and Sons (Publisher).

XI. Cooper, J. (2001). A MATLAB Companion for Multivariable Calculus.Academic Press.

XII. Dwyer - Joyce, R. S., Drinkwater, B. W. and Danohoe, C. J. (2003).“The Management Lubricant - Film Thickness Using Ultrasound".Proceedings of the Royal Society.Mathematical, Physical and Engineering Sciences. Volume 459, pp. 957 - 976.

XIII. Ferguson, C. R. and Kirkpatrick, A. T. (2001). ICE. ATS, $2^{\text {nd }}$ Edition. John Wiley and Sons (Publisher). NY, USA.

XIV. Grant, S. (2004).Piston Ring Design for Reduced Friction in Modern Internal Combustion Engines. MIT (Publisher).

XV. Herbst, H. M. (2007). Theoretical Modeling of the Cylinder Lubrication in Internal Combustion Engines and it'sInfluence on Piston Slap Induced Noise Friction and Wear. PhDThesis, Faculty of Mechanical Engineering, Technical University of Graz.

XVI. Johansen, T. A., England, O., Johannesen, E. A. and Kvamsdal, R. (2003).“Dynamics and Control of a Free - Piston Diesel Engine". ASME, 125, pp. 468 - 474.

XVII. Kanne, E. C. (2000). Engine Thermomangement for Fuel Consumption Reduction.Doctorial Thesis, Swiss Federal Institute of Technology, Zurich.

XVIII. Khurmi, R. and Gupta, J. (2007).Theory of Machines.EurasicPublishing House (PVT) Limited, New Delhi, $8^{\text {th }}$ Edition, pp. $72-381$.

XIX. Kikurch, T., Ito, S. and Nakayama,Y. (2003). "Piston Friction Analysis Using a Direct Injection Single- Cylinder Gasoline Engine". Journal for Society of Automobile Engineers, 2, pp. $53-58$.

XX. Motey, F. (2017). Modeling Fuel Consumption Under Changing Temperature Conditions in Internal Combustion Engines. PhD Thesis (Uncompleted), AIT/OUM

XXI. Taylor, R. I. and Evans, P. G. (2004)."In - situ Piston Measurements”.Prec. Institute of Mechanical Engineering, Journal of Engineering Tribology.Volume 218, pp. 185200.

XXII. Meyer, J. (2007). Engine Modeling of an Internal Combustion Engine.PhD Thesis, Ohio State University.

XXIII. Priest, M. and Taylor, C. M. (2002). "Lubrication of Automobile Engine Analysis".ElesevierScience Journal.

XXIV. Sandoval, D. and Heywood, J. (2003).“An Improved Friction Model Spark Ignition Engines".Journal for Society of Automobile Engineers. 
DOI : https://dx.doi.org/10.26808/rs.ed.i8v2.02

International Journal of Emerging Trends in Engineering and Development

Issue 8, Vol.2 (February- March 2018)

Available online on http://www.rspublication.com/ijeted/ijeted_index.htm ISSN 2249-6149

XXV. Sotaria, M., Bhatt, D. V. and Mistry, K. N. (2009)."Simulation of Piston Ring Friction Models ofSingle Cylinder Internal Combustion Engine".World Applied ScienceJournal, IDOSI Publications.

XXVI. Yue, H. (2008). Mesoscopic Fuel Consumption and Emissions Modeling.PhD Dissertation.Virginia Polytechnic Institute and State University. 